\title{
Pendampingan Orang Tua dalam Penggunaan Media Pembelajaran Daring Siswa Sekolah Dasar di Kelurahan Loa Buah
}

\author{
Annisa Qomariah*, Indah Eka Pertiwi2 \\ 1,2Universitas Widya Gama Mahakam, Kota Samarinda, Indonesia \\ *Corresponding Author: qomariahnisa@gmail.com
}

Info Artike1 Diterima : 16/01/2022 Direvisi: 18/01/2022 Disetujui: 19/01/2022

\begin{abstract}
Today is online learning in Indonesia is a new thing in the world of education. The obstacle that often occurs is that educators have difficulty in determining the media that can be used according to online learning. Another problem is the lack of parental assistance. Therefore, the researchers provided assistance to parents in elementary school online learning by using learning media. The strategies and methods used by researchers are online and offline. The results of the mentoring process obtained from the use of learning media are learning interest, increased student motivation. However, this is not a solution to the problem of ineffective online learning. The implementation of parental assistance in using learning media for elementary school students in Loa Buah sub-district contains many factors, both in terms of supporting and inhibiting factors. Supporting factors are motivation, high interest and talent of students, family support, community and school. While the inhibiting factors are the lack of facilities or infrastructure used for online and offline learning, the lack of an internet network, not being able to buy quotas, the lack of student discipline during face-to-face mentoring, lack of discipline in using masks, and others.
\end{abstract}

Keywords: Parental Assistance, Learning media, Online learning

\begin{abstract}
Abstrak. Pembelajaran daring saat ini di Indonesia merupakan hal yang baru di dunia pendidikan. Kendala yang yang terjadi sering terjadi yaitu pendidik kesulitan dalam menentukan media yang dapat digunkan sesuai pembelajarang daring. Persoalan lain yaiu minimnya pendampingan orang tua. Oleh sebab itu, peneliti melakukan pendampingan orang tua dalam pembelajaran daring sekolah dasar dengan menggunakan media pembelajaran. Strategi dan metode yang digunakan peneliti yaitu daring dan luring. Hasil dari proses pendampingan yang didapat dari penggunaan media pembelajaran adalah minat belajar, motivasi peserta didik yang meningkat. Namun hal itu tidak menjadi solusi masalah pembelajaran daring yang tidak efektif. Pelaksanaan pendampingan orang tua dalam menggunakan media pembelajaran bagi siswa sekolah dasar di kelurahan Loa Buah terdapat banyak faktor, baik dari sisi faktor pendukung maupun penghambat. Faktor pendukung yaitu motivasi, minat dan bakat yang tinggi peserta didik, dukungan keluarga, Masyarakat dan sekolah. Sedangkan faktor penghamabat minimnya fasilitas atau sarana prasarana yang digunakan untuk pembelajaran baik daring maupun luring, minimnya jaringan internet, tidak bisa membeli kuota, kurangnya disiplin peserta didik pada saat pendampingan secara tatap muka, kurangnya displin menggunakan masker, dan lain lain.
\end{abstract}

Kata Kunci: Pendampingan orang tua, Media pembelajaran, Pembelajaran daring

How to Cite: Qomariah, A., \& Pertiwi, I. E. (2022). Pendampingan Orang Tua dalam Penggunaan Media Pembelajaran Daring Siswa Sekolah Dasar di Kelurahan Loa Buah. Prima Abdika: Jurnal Pengabdian Masyarakat, 2(1), 6-13. https://doi.org/10.37478/abdika.v2i1.1575

Copyright (c) 2022 Annisa Qomariah, Indah Eka Pertiwi. This work is licensed under a Creative Commons Attribution-ShareAlike 4.0 International License.

\section{Pendahuluan}

Virus corona pertama kali ditemukan di kota wuhan, china pada akhir tahun 2019 (Lee,2020). Jumlah pasien penyebab dari covid 19 semakin meningkat setiap harinya, baik dalam negeri maupun luar negeri. Terlihat jumlah covid 19 mencapai 28,6 juta kasus dengan pasien terbanyak 6,4 juta di area Amerika serikat. Kasus covid 19 di Indonesia mencapai 214 rubu dengan kematian yang tinggi di Asia Tenggara (Kurnia, 2020).

Kebijakan yang dikeluarkan pemerintah Indonesia melalui social distancing dan pemberlakuan PSBB (Pembatasan Sosial Berskala Besar) pada bulan maret 2020 untuk memtus mata rantai (Azanella, 2020). Akibat dari pembatasan sosial berdampak oleh kegiatan peserta didik yang belajar di 
rumah., mulai dari perguruan tinggi hingga anak usia dini (Menteri Pendidikan dan Kebudayaan Republik Indonesia, 2020)

Pembelajaran daring dapat melalui proses pembelajaran jarak jauh melalui media internet serta alat penunjang seperti handpone dan komputer. Pembelajaran daring mempunyai keluasaan waktu belajar, serta dapat belajar dimanapun dan kapanpun. Peserta didik dapat berinteraksi dengan beberapa paltform media komunikasi seperti whatshap, zoom dan google classroom.

Kegiatan daring dalam pembelajaran mempunyai berbagai kekurangan diantaranya adalah penguasaan teknologi informasi terbatas yang dilakukan oleh guru dan peserta didik, sarana dan prasarana yang minim, akses internet yang terbatas, minimnya penyediaan anggaran yang dilakukan pembelajaran daring (Syah, 2020). Selain itu, pembelajaran daring menuntut orang tua untuk selalu mendampingi anak selama belajar dari rumah.

Tugas orang tua peserta didik pada pembelajaran daring harus membimbing dan mengawasi anak-anak saat belajar di rumah. Tapi tidak sedikit orang tua merasa kesulitas dalam mendampingi anaknya. Banyak orang tua yang tidak menguasai cara penggunaan teknologi sebagai media dalam pembelajaran daring (Wardani, 2020). Selain itu, kesulitan orang tua yaitu mengeluarkan biaya membeli kuota internet yang bertambah terus menerus. Kesulitan selanjutnya yang dirasakan orang tua adalah orang tua tidak banyak waktu untuk mendampingi anaknya belajar, karena kesibukan orang tua. Ada juga orang tua yang harus bekerja di luar rumah karena bergantung dari penghasilan harian. Dan kesulitan lainnya lagi yang dihadapi dalam pendampingan daring adalah orang tua orang tua merasa tidak mampu memahami pelajaran anaknya disekolah (Wulandari, 2021). Apalagi bagi orang tua merasa mereka tidak punya latar belakang pendidikan yang tinggi.

Dari hasil pengamatan dan pengetahuan secara langsung bahwa pembelajaaran daring yang diterapkan di kelurahan loa buah belum berjalan efektif seperti pembelajaran di dalam kelas. Penyebab tidak efektifnya pembelajaran daring terdapat kendala yang dihadapi guru-guru sepereti penggunaan media, strategi dan metode untuk pembelajaran daring.

Kendala terbesar di kelurahan Loa Buah saat pembelajaran daring yaitu media belajar, jaringan internet yang digunakan, minimnya pendampingan belajar dari orang tua. Media sebgai alat bantu perantara penyampaian materi dari guru-siswa pada saat pembelajaran berlangsung (Arsyad, 2011). Dalam penggunaan internet yang cukup tinggi bisa saja diatasi dengan menggunakan media pembelajaran yang membutuhkan internet yang lebih minim atau kecil. Akan tetapi masalah pendampingan orang tua dalam memahami materi agar peserta didik lebih aktif serta menyenangkan. Maka membutuhkan media pembalajaran interaktif dengan secara aktif mencapai tujuan pembelajaran dan aktif berinteraksi dengan media yang tersedia (Latuheru, 1988). Peserta didik sebenarnya dapat dapat mewujudkan interaksi yang baik melalui media yang dapat memacu minat dan semnagat belajar. Kondisi eksternal saat pandemic berwujud juga dari interaksi anatara guru dan peserta didik. Guru dalam interaksi dapat berprilaku positif serta akan berdampak pada prestasi cuku bagus dan meningkatkan keterampilan yang postif (Zaini, 2019). 
Dari pemaparan latar belakang diatas peneliti tertarik untuk mengabdi ke masyarakat tentang pendampingan orang tua dalam penggunaan media pembelajaran daring siswa sekolah dasar di kelurahan loa buah.

\section{Metode Pelaksanaan}

Penelitian ini dilakukan untuk mengetahui pendampingan orang tua penggunaan media pembelajaran siswa sekolah dasar. Jenis penelitian ini menggunakan penelitian kualitatif. Penelitian kualitatif dilakukan melalui pengumpulan data pada latar alamiah, dengan menggunakan metode dan dilakukan oleh orang atau peneliti yang tertarik secara alamiah.

Tempat penelitian dilaksanakan di daerah Loa Buah Kota Samarinda, Kalimantan Timur.Subyek penelitian diambil dengan Purposive Sampling dengan teknik pengambilan sampel sumber data dengan menggunakan pertimbangan tertentu. Mengambil sampel yaitu guru, orang tua dan siswa.

Instrumen penelitian merupakan pedoman tertulis tentang wawancara, pengamatan, dan pernyataan yang dipersiapkan untuk mendapatkan informasi atau pun suatu alat yang memenuhi persyaratan akademis sehingga dapat dipergunakan sebagai alat untuk mengukur suatu objek ukur atau mengumpulkan data. Teknik pengumpulan data adalah salah satu teknik terpenting dari suatu penelitian. Adapun teknik pengumpulan data yang akan digunakan pada penelitian ini yaitu wawancara dan dokumentasi.

\section{Wawancara.}

Wawancara sebagai percakapan tatap muka dimana salah satu pihak menggali informasi dari lawan bicara atau percakapan antara dua orang mengenai suatu subjek yang spesifik. Dengan ini peneliti akan mewawancarai guru, orang tua dan siswa, agar mengetahui pendampingan orang tua dalam penggunaan media pembelajaran siswa sekolah dasar.

2. Dokumentasi.

Dokumen-dokumen yang diambil berupa laporan tertulis dari pristiwa-pristiwa yang isinya terdiri dari penjelasan-penjelasan dan pemikiran-pemikiran, dan bisa dalam bentuk foto-foto dokumentasi penelitian.

Teknik analisis data dalam penelitian ini menggunakan Model Miles and Huberman. Mengemukakan bahwa aktivitas dalam analisis data kualitatif dilakukan secara interaktif dan berlangsung secara terus menerus sampai tuntas, sehingga datanya jenuh.

Keabsahan data merupakan hal yang sangat menentukan kualitas hasil penelitian. Teknik yang akan digunakan dalam pengecekan keabsahan data adalah triangulasi sumber. Dapat diartikan sebagai pengecekan data dari berbagai sumber. Maka dapat dikatakan triagulasi sumber untuk dapat menguji kredibilitas data dilakukan dengan pengecek data yang telah diperoleh melalui beberapa sumber. Maka penelitian ini, akan menggunakan triangulasi sumber dengan menggunakan pengamatan wawancara dan dokumentasi. 


\section{Hasil dan Pembahasan}

Kegiatan Pengabdian Masyarakat dengan tema pendampingan orang tua dalam penggunaan media pembelajaran daring siswa sekolah dasar di kelurahan loa buah. Pengabdian terlaksana dengan baik serta fasilitas yang di miliki sebelumnya sehingga tidak ada tekanan untuk tersedianya fasilitas yang digunakan proses pembelajaran daring. Masyarakat merasa terbantu dengan adanya pengabdian metode pembelajaran daring. Peserta didik cenderung melek teknologi informasi jadi lebih mudah untuk mengenal handpone atau gadget, namun kurang pemanfaatan yang kurang tepat karena minimnya pendampinga dan bimbingan. Peran orang tua sangat penting karena dengan adanya orang tua, anak menjadi semnagat dalam mendampingi belajar selama pandemic. Pendampingan orang tua mempunyai peran yang di perlukan agar anak-anak tetap bersemangat dan terkontrol dengan segala keterbatasan. Harapan dari kegiatan pengabdian ini akan penyemangat proses pendidikan dengan baik.

Metode pembelajaran saat digunakan adalah Google Classroom, zoom dan whatshapp membatu proses pembelajaran dengan lebih baik dan siswa menonton video tutorial dari setiap pelajaran yang mana sebelumnya hanya mengerjakan soal-soal saja tanpa adanya penjelasan sehingga peserta didik tidak tertarik untuk mengerjakan atau hanya sekedar mengerjakan saja.

Orang tua bertanggung jawab membantu anak dalam proses pembelajaran (Iftitah, 2020). Bentuk tanggung jawab orang tua salah satunya selama pembelajaran daring adalah mengisi daftar hadir siswa setiap harinya selama melaksanakan pembelajaran daring, orang tua biasanya mengisi melalui wa group kelas, namun terkadang masih terdapat beberapa orang tua yang terlambat dalam mengisi daftar hadir karena kesibukan seperti bekerja dan mengurus rumah sehingga daftar hadir diisi pada sore ataupun malam hari.

Dalam pengumpulan tugas terdapat beberapa orang tua yang mengirimkan tugas tepat waktu, namun terdapat pula orang tua yang terlambat atau lupa mengumpulkan tugas, mengumpulkan tugas digabungkan dengan tugas berikutnya dan tidak mengumpulkan tugas sama sekali. Hal tersebut dikarenakan $h p$ orang tua yang terbatas, tidak memiliki buku tematik serta paket internet dan wifi, sibuk bekerja dan pulang larut malam sehingga tidak sempat membantu anak mengerjakan tugas.

Proses pembelajaran secara daring, siswa sangat membutuhkan pendampingan dari orang tua (Asmuni dkk, 2020) terutama yang berada di kelas rendah. Selama melaksanakan pembelajaran daring siswa lebih banyak didampingi oleh ibu dan terkadang saja didampingi oleh ayah. Namun ada waktu dimana orang tua tidak dapat mendampingi anak selama belajar karena memiliki kegiatan mendadak, bekerja dan kurang memahami materi serta tugas pada mata pelajaran tertentu, sehingga digantikan oleh orang lain yang biasanya merupakan kerabat terdekat akan tetapi terdapat pula siswa yang secara mandiri mengerjakan tugas saat orang tua tidak dapat mendampingi namun, sebelum dikumpulkan kepada guru terlebih dahulu orang tua mengoreksi pekerjaan siswa.

Menyediakan fasilitas kepada anak merupakan tanggung jawab orang tua (Sundari dkk, 2018) dan merupakan hal yang penting untuk menunjang proses belajar anak selama pembelajaran daring. Namun tidak semua orang 
tua mampu memberikan fasilitas alat elektronik kepada anak seperti $h p$ serta wifi, paket data dan juga buku tematik. Beberapa orang tua yang mampu adalah orang tua yang memiliki pekerjaan yang tetap dan memiliki ekonomi yang berkecukupan, berbeda dengan orang tua yang berpenghasilan rendah dan memiliki tanggungan lain biasanya memiliki kendala pada jumlah $h p$ yang tidak memadai serta kapasitas $h p$ yang kurang, tidak mampu membeli paketan data secara terus menerus sehingga diberi tumpangan oleh tetangga sekitar serta tidak mampu membelikan buku tematik untuk anak.

Kunci dari pembelajaran daring dapat dilaksanakan adalah kemampuan menggunakan teknologi dan ketersediaan teknologi (Asmuni 2020). Rata-rata orang tua hanya menggunakan alat elektronik $h p$ selama pembelajaran daring dan semuanya mampu menggunakan, selain $h p$ perangkat elektronik lain yang diperlukan adalah wifi. Untuk ketersediaan perangkat elektronik tidak semua orang tua mampu dikarenakan kapasitas $h p$ yang kecil, hanya memiliki satu $h p$ yang digunakan lebih dari satu orang anak untuk belajar dan jaringan internet/wifi yang masih bergantung dengan menumpang dengan orang lain.
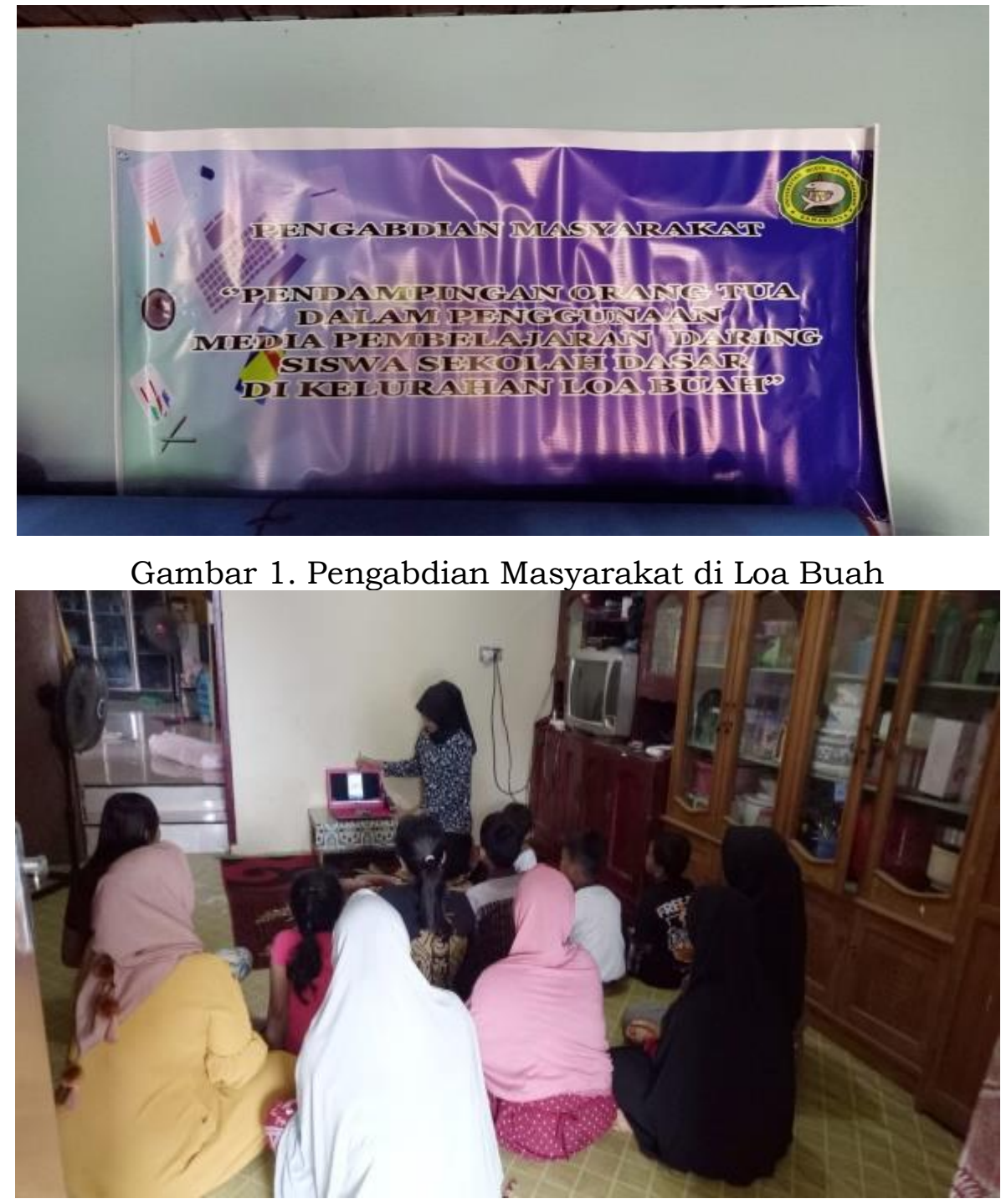

Gambar 2. Penyuluhan Tutorial penggunaan media kepada orang tua 


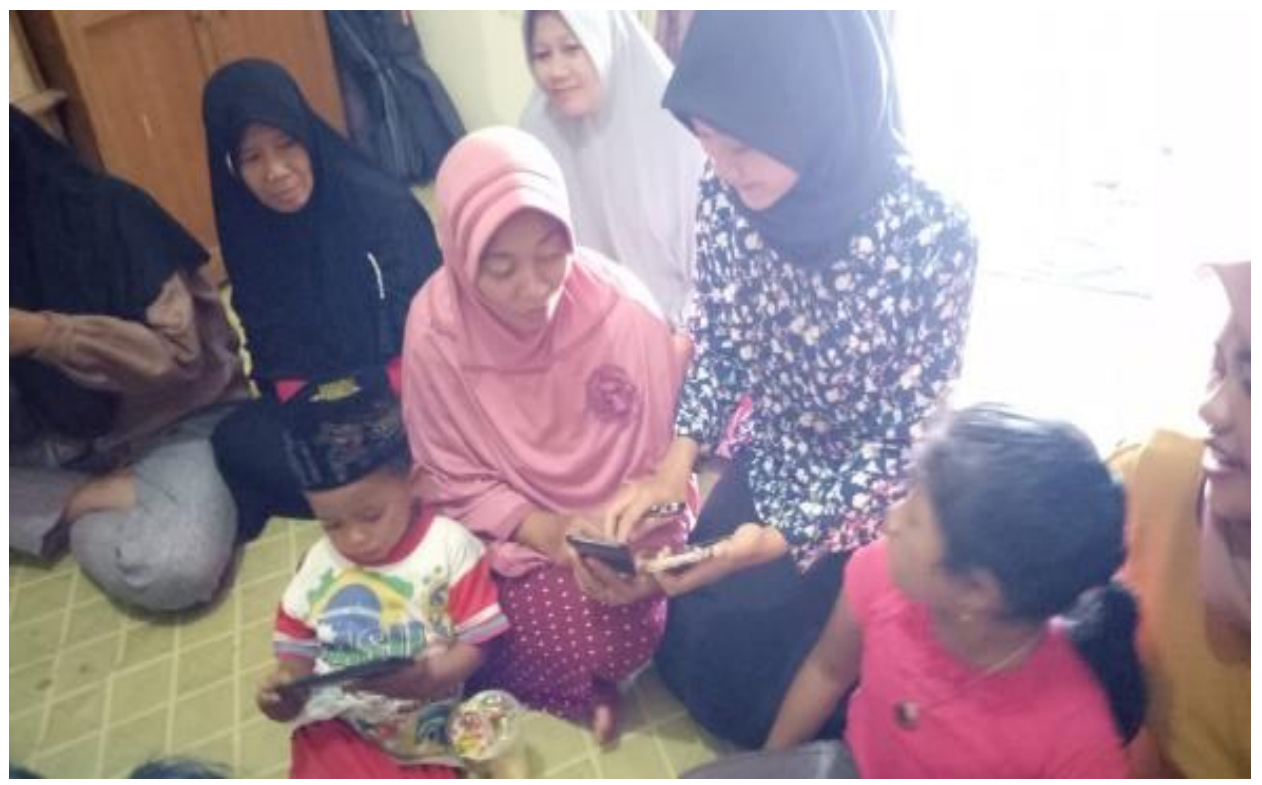

Gambar 3. Pemberian Edukasi kepada orang tua mengenai pembelajaran daring

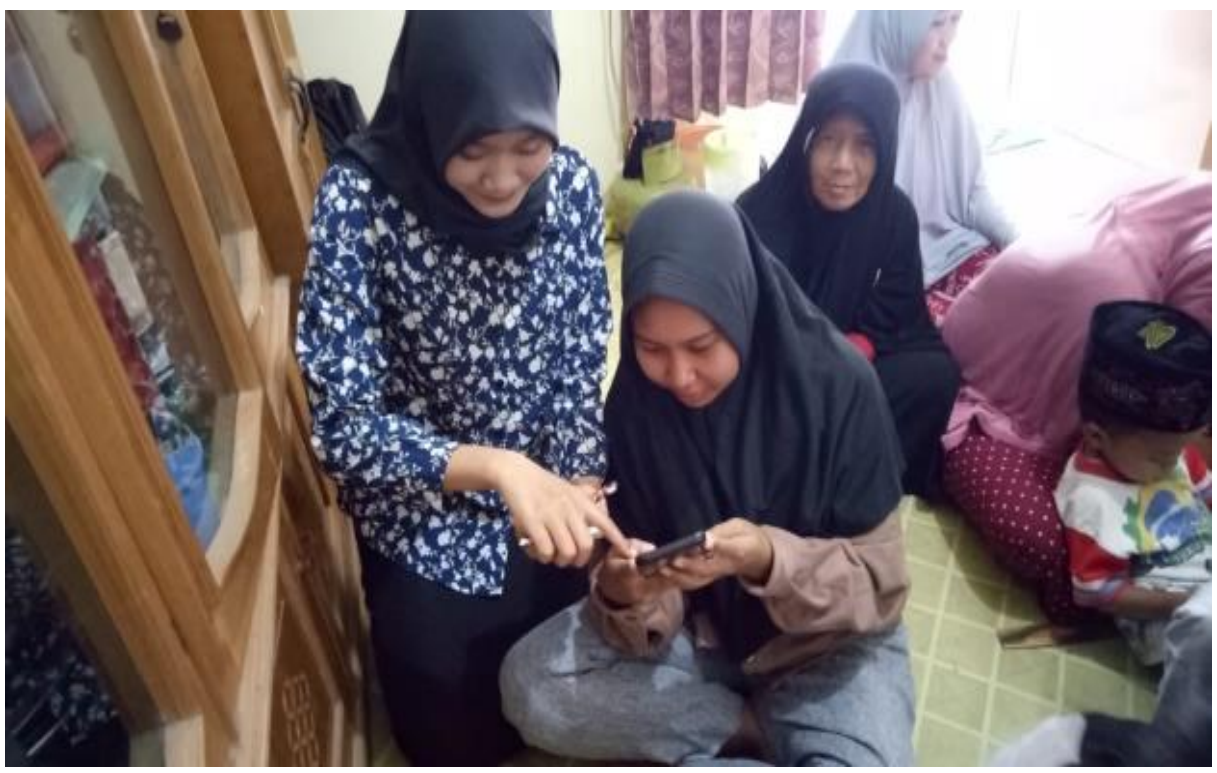

Gambar 4. Pemberian Edukasi kepada orang tua mengenai pembelajaran daring

Selama melaksanakan pembelajaran daring, orang tua mengambil peranan penting dalam perkembangan belajar anak baik secara kognif, afektif dan psikomotorik (Kusumaningrum dkk, 2020). Namun orang tua siswa cenderung kurang aktif menanyakan perkembangan belajar anak kepada guru karena kebanyakan orang tua merasa lebih tau mengenai perkermbangan belajar anak baik dalam aspek pengetahuan, sikap dan keterampilan selama pembelajaran daring, alasan lain yang menyebabkan orang tua tidak aktif dalam menanyakan perkembangan belajar anak dikarenakan kesibukan bekerja, mengurus rumah dan mengurus anak yang masih balita atau anak lain yang membutuhkan perhatian lebih. Adapun hal yang orang tua tanyakan kepada guru adalah mengenai kesulitan materi serta tugas, pengumpulan rapot dan kerterlambatan mengumpulkan tugas. 


\section{Simpulan dan Tindak Lanjut}

Berdasarkan hasil pengabdian yang telah dilakukan dapat ditarik kesimpulan bahwa orang tua sangat mengambil peran penting dalam mendampingi dalam penggunaan media pembelajaran daring siswa seperti memberikan fasilitas yang menunjang selama pembelajaran daring dan memberikan bantuan ketika siswa mengalami kesulitan belajar, namun dalam proses pelaksanaannya tentunya terdapat berbagai hambatan yang ditemui oleh orang tua yang datang dari orang tua sendiri dan hambatan yang datang dari luar.

\section{Daftar Pustaka}

Arsyad, A. (2011) Media Pembelajaran. (Jakarta : PT Raja Grafindo Persada .

Asmuni, A. 2020. "Problematika Pembelajaran Daring Di Masa Pandemi Covid-19 Dan Solusi Pemecahannya.” Jurnal Paedagogy 7(4):281. doi: 10.33394/jp.v7i4.2941.

Azanella, L. A. (2020, April). Apa Itu PSBB hingga Jadi Upaya Pencegahan Covid-19? Editor: Inggried Dwi Wedhaswary. Kompas.Com.

Iftitah, S.L., \& Anawaty, M.F. (2020). "Peran Orang Tua Dalam Mendampingi Anak Di Rumah Selama Pandemi Covid-19." JCE (Journal of Childhood Education) 4(2):71. doi: 10.30736/jce.v4i2.256.

Kurnia, T. (2020). Liputan6 Update 13 September 2020 26,6 Juta Kasus Covid 19 di Dunia 919 Ribu Meninggal.pdf. https://www.liputan6.com/global/read/4354938/update-13-

september-266- jutakasus- covid-19-di-dunia-919-ribu-meninggal

Kusumaningrum, B., Kuncoro, K.S., \& Arigiyati, T.A. (2020). Pendampingan Orangtua Dalam Pembelajaran Daring Di Sekolah Dasar: Evaluasi Pembelajaran Daring Selama Masa Pandemi Covid-19. Jurnal Pendidikan Guru Sekolah Dasar, 04(2):142-50.

Lee, A. (2020). Wuhan novel coronavirus (COVID-19): why global control is challenging? In Public Health (Vol. 179, pp. A1-A2). The Royal Society for Public https://doi.org/10.1016/j.puhe.2020.02.001

Health.

Menteri Pendidikan dan Kebudayaan Republik Indonesia. (2020). Surat Edaran Nomor 4 Tahun 2020 Tentang Pelaksanaan Kebijakan Pendidikan Dalam Masa Darurat Penyebaran Coronavirus Disease (COVID-19). Republik Indonesia. https:// pusdiklat.kemdikbud.go.id/surat-edaran-mendikbud-no-4tahun-2020- tentang-pelaksanaan-kebijakan- pendidikan-dalam-masadarurat- penyebarancorona- virus-disease-covid-1-9/

Pendidikan, K., Kebudayaan, D. A. N., \& Indonesia, R. (2020). Pentingnya Bermain Bagi Anak. 1-32.

Sundari, S., \& Sinuraya, Y. A. (2018). "Langkah Kakiku Setelah SMA". Jakarta: Publica Institute Jakarta.

Wardani, A., \& Ayriza, Y. (2020). Analisis Kendala Orang Tua dalam Mendampingi Anak Belajar di Rumah Pada Masa Pandemi 
Covid-19. Jurnal Obsesi : Jurnal Pendidikan Anak Usia Dini, 5(1), 772. https://doi.org/10.31004/obsesi.v5i1.705

Wulandari, H., \& Purwanta, E. (2021). Pencapaian Perkembangan Anak Usia Dini di TK selama Pembelajaran Daring saat Pandemi Covid-19. Jurnal Obsesi : Jurnal Pendidikan Anak Usia Dini, 5(1), 452-462. https://doi.org/ 10.31004/obsesi.v5i1.626

Zaini, N. (2019). Konsep Pendidikan Humanis dan Implementasinya dalam Proses Belajar Mengajar. Karangan: Jurnal Kependidikan, Pembelajaran dan Pengembangan, 10 (01), 62-72 